\title{
Bradysia aff. impatiens and Bradysia aff. ocellaris in the semi-hydroponic strawberry production system in Southern Brazil
}

\author{
Adriane da Fonseca Duarte ${ }^{1^{*}(\mathbb{D})}$ Juliano Lessa Pinto Duarte ${ }^{1}$ (iD \\ Patrícia da Silva Grinberg $^{2}$ Uemerson Silva da Cunha ${ }^{1}$ (D)
}

${ }^{1}$ Departamento de Fitossanidade, Faculdade de Agronomia Eliseu Maciel (FAEM), Universidade Federal de Pelotas (UFPel), 96010-900, Pelotas, RS, Brasil. E-mail: adriane.faem@hotmail.com. ${ }^{*}$ Corresponding author. ${ }^{2}$ Clínica Fitossanitária, Emater/Embrapa Clima Temperado, Pelotas, RS, Brasil.

\begin{abstract}
Soilless cultivation of strawberry is in expansion in Brazil due to factors like the reduction of phytosanitary problems and the possibility of extending the crop period, as well as the ergonometric facility for management of the culture. However, black fungus gnats (Sciaridae, Diptera) are ubiquitous pests in the greenhouse production system, causing direct and indirect damage to plants. ThIS study evaluated the occurrence of black fungus gnats species in semi-hydroponic cultivation of strawberry and to identify the species, as well as to describe the symptoms in infested plants. The research was developed in commercial productions of strawberry, in five municipalities (Arroio do Padre, Canguçu, Capão do Leão, Pelotas and Turuçu) during July to December 2017, where adult samples were collected twice a month, with petri dish traps containing water and neutral detergent placed inside the greenhouses between the plants. A total of 2030 adult gnats belonging to two species were collected. Bradysia aff. impatiens, accounted with $90.79 \%$ of the total, and Bradysia aff. ocellaris, accounted with $9.21 \%$. In order to assist the correct determination of species, males of both species were identified and illustrated. With respect to the symptoms observed during the research, it was possible to verify since the wilted crown of plants to the death of plants, which were confirmed by the presence of larvae in the root system. As the occurrence of these insects is recent in strawberry, there is no pesticide registered in Brazil, so management strategies (cultural, physical, and sanitary) also are discussed. Key words: fungus gnats, Sciaridae, integrated pest management, greenhouse pest.
\end{abstract}

Bradysia aff. impatiens e Bradysia aff. ocellaris em sistemas de produção semi-hidropônico de morango no Sul do Brasil

RESUMO: $O$ cultivo de morango sem solo esta em expansão no Brasil, devido a fatores como a redução de problemas fitossanitários e a possibilidade de produção por um período maior, assim como a facilidade ergométrica para o manejo da cultura. No entanto, black fungus gnats (Diptera: Sciaridae) são pragas onipresentes no sistema de produção de estufas, causando danos diretos e indiretos às plantas. O objetivo deste trabalho foi avaliar a ocorrência de espécies de black fungus gnats em cultivo de morango semi-hidropônico e identificar as espécies, assim como descrever os sintomas observados em plantas infestadas. $O$ trabalho foi desenvolvido em produção de morango comercial, em cinco municípios (Arroio do Padre, Canguçu, Capão do Leão, Pelotas e Turuçu) durante Julho a Dezembro de 2017, onde os adultos foram coletados duas vezes por mês, com armadilhas de placa de Petri, contendo água e detergente neutro, as quais eram colocadas dentro das estufas entre as plantas. Um total de 2.030 mosquitos adultos pertencentes a duas espécies foram coletados. Bradysia aff. impatiens, com 90,79\% do total, e Bradysia aff. ocellaris, com 9,21\%. Para auxiliar na correta determinação das espécies, os machos de ambas as espécies foram identificados e ilustrados. Com relação aos sintomas observados durante o trabalho, foi possível verificar desde a coroa murcha até a morte das plantas, em que foram confirmados pela presença de larvas no sistema radicular. Como a ocorrência desses insetos é recente em morango, não há agrotóxico registrado no Brasil, então estratégias de manejo (cultural, físico e sanitário) também são discutidas. Palavras-chave: fungus gnats, Sciaridae, manejo integrado de pragas, praga de estufas.

\section{INTRODUCTION}

Strawberry planted area in Brazil reaches about 4.000 hectares and has an estimated production of more than 105 thousand tons per year (RESENDE, 2018). Although, the country is not one of the top ten strawberry producers in the world, the culture has significant social and economic importance, aggregating family labor (CECATTO et al., 2013). The fruit has great nutritional appeal due to its functional properties as a good source of antioxidants, mainly given to its high vitamin $\mathrm{C}$ and phenolic contents (PINELI et al., 2011). In order to attend the consumer market, it is necessary to increase production and sustainably produce, what improves consumer acceptance.

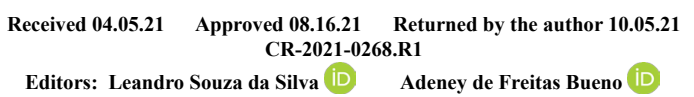


Strawberry may be cultivated in soil or soilless systems (semi-hydroponic system), being cultivated mainly in the soil by Brazilian producers. In this production system the susceptibility of most strawberry cultivars to soil-borne pathogens is high (JAFARNIA et al., 2010; PALENCIA et al., 2016), what increases the excessive use of pesticides by producers (CECATTO et al., 2013). In the soilless systems, the support base for the substrate may be in tubular plastic packaging, fiber cement tiles, PVC gutters, or wood, where the substrates (organic, wooded rice husk, sand or coconut fiber) are placed free of soil pathogens (GONÇALVES et al., 2016) besides providing a suitable microclimate for plants.

Therefore, soilless cultivation systems is an alternative to minimize the problems, because the plants are cultivate inside greenhouses, protected from wind, hail, rain, frost and low temperatures. This system also reduces the prevalence of pests and diseases, and allows out of season production, increasing yield (JAFARNIA et al., 2010; CECATTO et al., 2013). Nevertheless, this system is still subject to different issues that can affect the production.

In greenhouse crop-production systems, black fungus gnats (Diptera: Sciaridae) are common pests (BRAUN et al., 2012). The small gnats of this family are extremely widespread and its species are adapted to a wide variety of climates (COLLESS \& MCALPINE 1991). These small flies are considered the major insect pests of greenhouse production systems (CLOYD 2015) since they cause direct (larval feeding) and indirect damage through the spread of fungi propagules such as Fusarium, Phytium and Thielaviopsis (GARDINER et al., 1990; ELHAMALAWI 2008). Its larvae feed on a wide-range of horticultural crops such as tomatoes, sweet peppers, lettuces, onions and ornamental flowers (SAN-BLAS et al., 2017), Eucalyptus nurseries (SANTOS et al.,
2012) besides to be the main pest in mushroom crops, nurseries and greenhouse (MENZEL et al., 2003; Cloyd 2008) and adults can be a nuisance factor in Pinus timber yards (SCHÜHLI et al., 2014).

Present in semi-hydroponic strawberry cultivation since 2005, Bradysia sp. demonstrate to be an important pest in this system, since occasioned the dead plants (19.5\% of plants) during forty five days (RADIN et al., 2009); however, the authors did not identify the species for Brazil. The correct identification of the species is extremely important to assist in the development of research on biology, ecology and control of the gnats.

There is no systematic survey of the strawberry sciarid pest species for the Neotropical region and literature on these species is scarce. More studies are needed in order to understand its biodiversity, mainly for economically important species. Therefore, this study identified the species of the black fungus gnats in semi-hydroponic strawberry cultivation, as well as to describe the symptoms showed by infested plants. Moreover, management practices are discussed in order to provide control measures to producers.

\section{MATERIALS AND METHODS}

\section{Study sites}

This study was carried out in strawberry commercial production greenhouses, located in five municipalities (Table 1) during five months (July to December 2017). Strawberry was planted in plastic bags filled with a mixture of burnt rice peels and commercial substrate and cultivated inside greenhouses. All others management practices (irrigation, fertilization and integrated pest management) were carried out in accordance with the technical recommendations and requirements of the culture.

Table 1 - Information about the collection sites (municipality, geographical coordinates, strawberry cultivar) of black fungus gnats (Sciaridae: Diptera) in Rio Grande do Sul State.

\begin{tabular}{|c|c|c|}
\hline Municipality & Geographical coordinates & Cultivar \\
\hline Arroio do Padre & $31^{\circ} 29^{\prime} 15.1^{\prime \prime} \mathrm{S}, 52^{\circ} 21^{\prime} 39.9^{\prime \prime} \mathrm{W}$ & Albion; San Andreas \\
\hline Canguçu & $31^{\circ} 27^{\prime} 57.0^{\prime \prime} \mathrm{S}, 52^{\circ} 35^{\prime} 58.0^{\prime \prime} \mathrm{W}$ & Albion; San Andreas \\
\hline Capão do Leão & $31^{\circ} 48^{\prime} 10.8^{\prime \prime} \mathrm{S}, 52^{\circ} 25^{\prime} 06.24^{\prime \prime} \mathrm{W}$ & Aromas; Camarosa \\
\hline Pelotas & $31^{\circ} 38^{\prime} 57.7^{\prime \prime} \mathrm{S}, 52^{\circ} 22^{\prime} 39.0^{\prime \prime} \mathrm{W}$ & San Andreas \\
\hline Turuçu & $31^{\circ} 26^{\prime} 29.6^{\prime \prime S}, 52^{\circ} 13^{\prime} 31.0^{\prime \prime} \mathrm{W}$ & Camino Real \\
\hline
\end{tabular}




\section{Collection of black fungus gnats}

Adult samples were collected inside the greenhouses twice a month. Petri dish traps containing water and neutral detergent, were placed amongst the plants in order to capture the gnats. The traps were removed 48 hours after the installation and sent to the Laboratory of Acarology (LabAcaro) at Faculdade de Agronomia Eliseu Maciel, Universidade Federal de Pelotas (FAEM/UFPEL), Pelotas, Rio Grande do Sul state, where initially the black fungus gnats adults were examined and counted with the help of a stereoscopic microscope (40x) and then preserved in $70 \%$ alcohol.

\section{Species preparation}

Male specimens were kept for approximately 120 minutes in a solution of $10 \%$ $\mathrm{KOH}$ for clarification, and then dissected and mounted as permanent slides using Hoyer's medium, (distiled water $40 \mathrm{ml}$, glicerin $20 \mathrm{ml}$, cloral hidrate $200 \mathrm{~g}$ and arabic gome $30 \mathrm{~g}$ ) according to MORAES $\&$ FLECHTMANN (2008). Slides were kept in an incubator at $50^{\circ} \mathrm{C}$ for ten days in order to dry out and clarify the specimens. Species determination was done under phase contrast microscope following Lane, 1959, MENZEL et al., 2003, and MOHRIG et al., 2012. Taxonomically relevant structures were photographed using a camera attached to the microscope. Photographs of males' hypoppygia were then enhanced by drawing over the images to highlight important morphological characters using Adobe Illustrator software.

Some specimens were photographed before clarification, in order to compare important taxonomic characteristics of the species found. Voucher specimens are deposited in the entomological collection Padre Jesus Santiago
Moure, Departamento de Zoologia, Universidade Federal do Paraná (DZUP).

\section{RESULTS}

A total of 2030 adults of sciarid gnats were collected in strawberry commercial production greenhouses. All individuals belonged to Bradysia genus, with the species Bradysia aff. impatiens (Johannsen, 1912) accounting with $90.79 \%$ and Bradysia aff. ocellaris (COMSTOCK, 1882) with only $9.21 \%$ (Table 2 ). In this work, $B$. aff. ocellaris was found in high quantity only in the municipality of Capão do Leão, accounting with 184 specimens collected $(9.06 \%$ of the total). In the other collection sites, this species was absent or very rare, accounting with $0.00-0.10$ percent of total (Table 2).

Symptoms of sciarid infestation included the wilting of the plants crown (Figure 1A), drying of the leaves edges (Figure 1B), wilting plants (Figure 1C) and death of the plants (Figure 1D).

The two species of Bradysia reported in strawberry plants in this study are very morphologically similar. Since one of the bases of IPM is the correct identification of the species, we provided the morphological characteristic that distinguishes both species. These characteristics are highlighted in figures 2 and 3.

\section{Morphological identifications}

The easiest way to distinguish both species is by the presence of a yellowish band on the pleura of $B$. aff. ocellaris (Figure 2D and 2E) while $B$. aff. impatiens lacks this band (Figure 2A and 2B). As can be seen in figures $2 \mathrm{C}$ and $2 \mathrm{~F}, B$. aff. impatiens scape, pedicel and all segments of antenna are blackish, while $B$. aff. ocellaris antenna presents the scape, the

Table 2 - Total number and proportion (\%) in parenthesis of Bradysia aff. impatiens (Johannsen, 1912) and Bradysia aff. ocellaris (Comstock, 1882) found in strawberry production facilities.

\begin{tabular}{|c|c|c|c|c|c|}
\hline \multirow[t]{2}{*}{ Municipality } & \multicolumn{2}{|c|}{--------Bradysia aff. impatiens-------- } & \multicolumn{2}{|c|}{----------Bradysia aff. ocellaris---------- } & \multirow[t]{2}{*}{ Total } \\
\hline & male & female & male & female & \\
\hline Arroio do Padre & $83(4.09)$ & $38(1.87)$ & $1(0.05)$ & $0(0.00)$ & $122(6.01)$ \\
\hline Canguçu & $559(27.54)$ & $48(2.36)$ & $0(0.00)$ & $0(0.00)$ & $607(29.90)$ \\
\hline Capão do Leão & $711(35.02)$ & $179(8.82)$ & $161(7.93)$ & $23(1.13)$ & $1074(52.90)$ \\
\hline Pelotas & 40 (1.97) & 40 (1.97) & $2(0.10)$ & $0(0.00)$ & $82(4.04)$ \\
\hline Turuçu & $114(5.62)$ & $31(1.53)$ & $0(0.00)$ & $0(0.00)$ & $145(7.15)$ \\
\hline Total & $1507(74.24)$ & $336(16.55)$ & $164(8.08)$ & $23(1.13)$ & $2030(100)$ \\
\hline
\end{tabular}

Ciência Rural, v.52, n.7, 2022. 




pedicel and the first two segments whitish, contrasting with the rest of the flagellomeres.

\section{DISCUSSION}

Sciaridae gnats are very common in greenhouses, nurseries, mushroom farms and other environments with high level of organic matter, since sciarid larvae are major primary decomposers of plant debris (MOHRIG et al., 2012). However, some Bradysia species are major insect pests in commercial greenhouses, especially during the propagation phase, when the plant root systems are starting to develop (CLOYD \& ZABORSKI 2004), as well as after the transplantation of seedlings. When the plants are still not well established, the root system is more susceptible to damage, so it is very important to reduce the population of sciarid gnats at this stage, strengthening the need to implement integrated pest management, through the monitoring with yellow adhesive traps.

Although, symptoms of sciarid infestation are commonly observed in protect crops in Brazil, studies for species identification have not been performed. RADIN et al., (2009) made the only study about semi-hydroponic strawberry cultivation regarding sciarids, but the authors did not identify the species of Bradysia they collected. Therefore, this is the first paper with species identification in semi-hydroponic strawberry cultivation. The species documented here were reported for the first time in Brazil in 2003, on cultivated mushroom Agaricus blazei (MENZEL et al., 2003). However, in cultivated crops, this is the first record for Brazil. This is probably because the cultivation of strawberry inside greenhouses, with semi-hydroponic system, is relatively recent in the country. Also, farmers do not associate plant damage with the occurrence of gnats.

The correct identification of these species in strawberry is extremely important for management, because $B$. impatiens is a common greenhouse crop pest that causes economic losses worldwide (CLOYD 2008) and was already reported in strawberry plants in the other countries such Japan and Australia (ARIMOTO et al., 2018; BROADLEY et al., 2018). Among the sciarid species collected in cultivated plants inside greenhouses in Australia, B. impatiens was the most frequently encountered species, corresponding to $62.6 \%$ of total (BROADLEY et al., 2018).

In greenhouse strawberry plants in Japan, for example, this species is considered the most important pest of the genus, because its larvae are known to damage the crowns of plants during feeding (ARIMOTO et al., 2018). Also, adults can contribute to the introduction and rapid spread of certain pathogens, because it can easily adhered to 


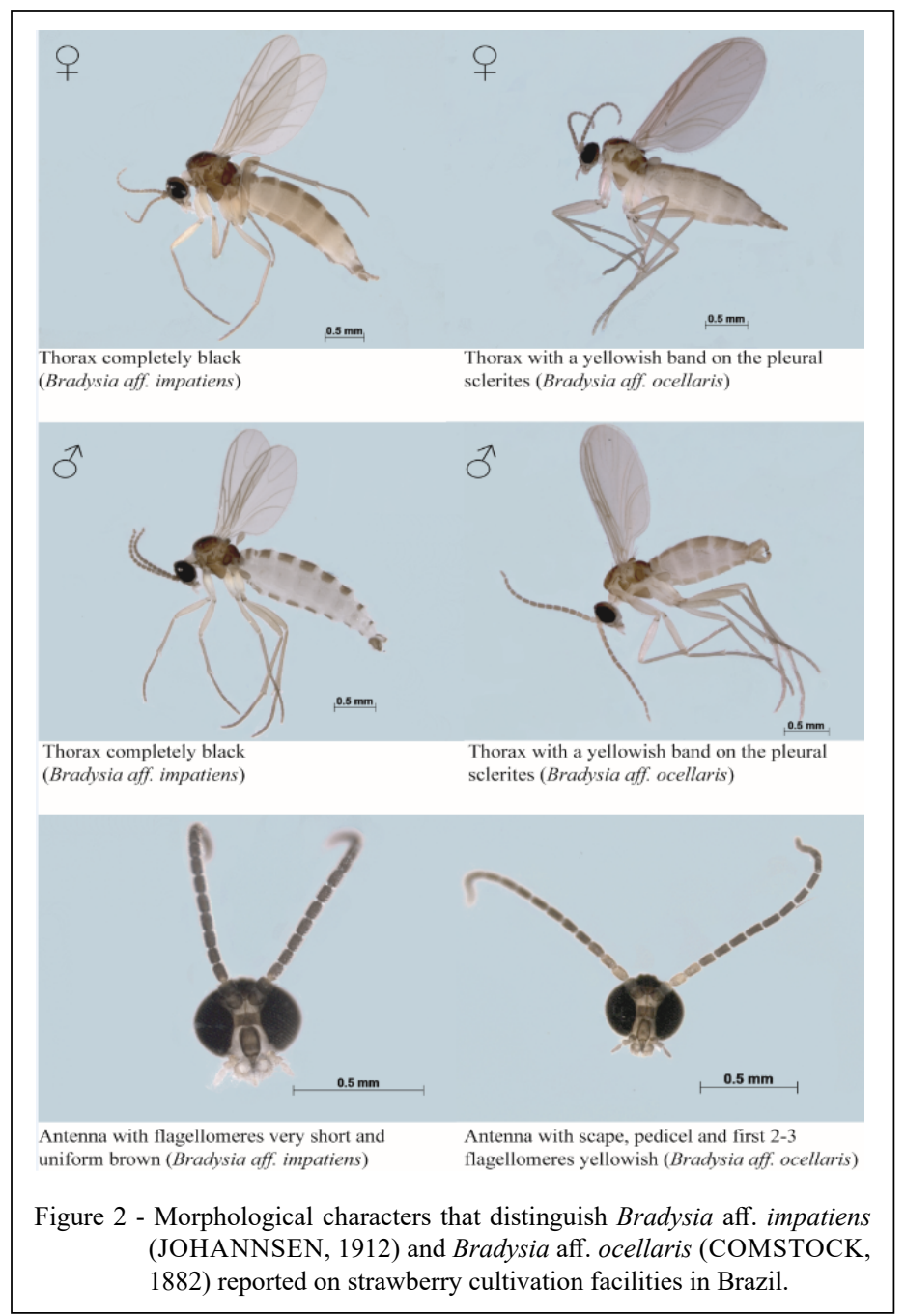

the flying adult insects (EL-HAMALAWI 2008). $B$. impatiens is a potential vector of Fusarium sp. to strawberry plants (NAM et al., 2017), therefore, it is very important to reduce the population of sciarid gnats inside greenhouses (GORSKA-DRABIK et al., 2011). Furthermore, the correct determination of the gnat species is essential to the proper management.

Although, the two species reported in this study are morphologically very similar (MENZEL et al., 2003). The main characteristics that distinguish this two species are mentioned in figures 2 and 3. Nevertheless, the management practices are similar for both species; there are no registered synthetic pesticides for them in Brazil (AGROFIT, 2019). Therefore, it is very important to implement alternative management strategies that minimize damage and reduce the insect population, such as biological control of $B$. aff. ocellaris (DUARTE et al., 2021) cultural, physical, and sanitation measures (CLOYD 2015).

Management strategies that may be adopted to reduce the establishment of larvae are: installation of the greenhouses away from sources rich in organic matter and with good ventilation; maintenance of a clean environment inside the greenhouse, in order to avoid the establishment of fungi and algae; proper irrigation management, avoiding excess moisture in the substrate; and constant monitoring with yellow adhesive traps.

Humid and dark environments, rich in organic matter are ideal conditions for the development of their food source, since larvae of these insects feed on fungi, algae and decaying organic matter (AGUILERA \& ORTEGA 1996;

Ciência Rural, v.52, n.7, 2022. 




MANSILLA \& PASTORIZA 2001). Therefore, it is necessary to reduce these factors that contribute to the development of black fungus gnats, as well as the monitoring with yellow adhesive traps, which helps in capturing adults, being an indirect control measure. Also, the identification of species that cause damage in this crop will serve as a basis for other studies, which aim to evaluate tools (biological and chemical) for the management of these species in Brazil.

\section{ACKNOWLEDGMENTS}

We thank the Brazilian Coordenação de Aperfeiçoamento de Pessoal de Nivel Superior (CAPES) for the scholarship to the first author (Proc. no. 88882.182253/2018-01) and to second author (Proc. no. 88882.306693/2018-01).

\section{DECLARATION OF CONFLICT OF INTEREST}

The authors declared do not have potential conflicts of interest with respect to the research, authorship, and/or publication of this publication.

\section{AUTHORS' CONTRIBUTIONS}

All authors contributed equally for the conception and writing of the manuscript. All authors critically revised the manuscript and approved of the final version.

\section{REFERENCES}

AGROFIT, Ministério da Agricultura, Pecuária e Abastecimento (MAPA). Sistema de agrotóxicos fitossanitários, 2019. Available 
from: $\quad<$ http://agrofit.agricultura.gov.br/agrofit_cons/principal_ agrofit_cons>. Accessed: Sept. 13, 2019.

AGUILERA, A. P., ORTEGA, F. K. Bradysia coprophila (LINTNER) (Diptera: Sciaridae) em trebol rosado (Trifolium pratense L.). Agricultura Técnica, v.56, p.135-138, 1996. Available from: https://www.cabdirect.org/cabdirect/ abstract/19981102025. Accessed: Apr. 01, 2021.

ARIMOTO, M. et al. Molecular marker to identify the fungus gnat, Bradysia sp . (Diptera: Sciaridae ), a new pest of Welsh onion and carrot in Japan. Applied Entomology Zoology, v.53, p.1-6, 2018. Available from: <https://doi.org/10.1007/s13355-018-0563-y>. Accessed: Apr. 01, 2021. doi: 10.1007/s13355-018-0563-y.

BRAUN, S. E., et al. Larval Bradysia impatiens (Diptera: Sciaridae) Potential for Vectoring Pythium Root Rot Pathogens Phytopathology, v.102, p.283-289, 2012. Available from: <http:// dx.doi.org/10.1094/PHYTO-09-11-0262>. Accessed: Apr. 01, 2021. doi: 10.1094/PHYTO-09-11-0262.

BROADLEY, A., et al. Black fungus gnats (Diptera: Sciaridae) found in association with cultivated plants and mushrooms in Australia, with notes on cosmopolitan pest species and biosecurity interceptions. Zootaxa, v.4415, p.201-242, 2018. Available from: $<$ https://doi.org/10.11646/zootaxa.4415.2.1>. Accessed: Apr. 01, 2021. doi: 10.11646/zootaxa.4415.2.1

CECATTO, A. P. et al. Culture systems in the production and quality of strawberry cultivars. Acta Scientiarum, v.35, p.471478, 2013. Available from: <http://old.periodicos.uem.br/ojs/ index.php/ActaSciAgron/article/view/16552/pdf_1>. Accessed: Apr. 01, 2021. doi: 10.4025/actasciagron.v35i4.16552.

CLOYD, R. A. Ecology of fungus gnats (Bradysia spp.) in greenhouse production systems associated with disease-interactions and alternative management strategies. Insects, v.6, p.325-332, 2015. Available from: <https://doi.org/10.3390/insects6020325>. Accessed: Apr. 01, 2021. doi: 10.3390/insects6020325.

CLOYD, R. A. Management of fungus gnats (Bradysia spp.) in greenhouses and nurseries. Floriculture and Ornamental Biotechnology, v.2, p.84-89, 2008. Available from: <http:// www.globalsciencebooks.info/Online/GSBOnline/images/0812/ FOB_2(1\&2)/FOB_2(2)84-89o.pdf>. Accessed: Apr. 01, 2021.

CLOYD, R. A., ZABORSKI, E. R. Fungus gnats, Bradysia spp. (Diptera: Sciaridae), and other arthropods in commercial bagged soilless growing media and rooted plant plugs. Journal Economic Entomology, v.97, p.503-510, 2004. Available from: $<$ https://doi. org/10.1603/0022-0493-97.2.503>. Accessed: Apr. 01, 2021. doi: $10.1603 / 0022-0493-97.2 .503$

COLlESS, D. H., MCALPINE, D. K. Diptera. In: The Insects of Australia - A textbook for students and research workers. pp 717-786, 1991.

DUARTE, A. da F. et al. Evaluation of Cosmolaelaps brevistilis and Stratiolaelaps scimitus (Mesostigmata: Laelapidae) as natural enemy of Bradysia aff. ocellaris (Diptera: Sciaridae). Systematic and Applied Acarology, v.26, p.1293-1300, 2021. Available from: $<$ https://www.biotaxa.org/saa/article/view/64566>. Accessed: Jul. 21, 2021. doi: 10.11158/saa.26.7.9.

EL-HAMALAWI, Z. A. Acquisition, retention and dispersal of soilborne plant pathogenic fungi by fungus gnats and moth flies.
Annals of Applied Biology, v.153, p.195-203, 2008. Availale from: $\quad<$ https://doi.org/10.1111/j.1744-7348.2008.00247.x> Accessed: Apr. 01, 2021. doi: 10.1111/j.1744-7348.2008.00247.x.

GARDINER, R. B., et al. Ingestion of Pythium spp. by larvae of the fungus gnat Bradysia impatiens (Diptera:Sciaridae). Annals of Applied Biology, v.116, p.205-212, 1990. Available from: $<$ https://doi.org/10.1111/j.1744-7348.1990.tb06600.x>. Accessed: Apr. 01, 2021. doi: 10.1111/j.1744-7348.1990.tb06600.x.

GONÇALVES, M. A. et al. Produção de Morango fora do solo. Embrapa Clima Temperado- Documento 410, 2016. Available from: < https://ainfo.cnptia.embrapa.br/digital/bitstream/ item/145140/1/Documento-410.pdf >. Accessed: Apr. 05, 2021.

GORSKA-DRABIK, E., et al. Effectiveness of coloured sticky traps in monitoring of Ctenosciara hyalipennis (Meigen, 1804) (Diptera: Sciaridae) on exotic plant species in greenhouse. Acta Scientiarum Polonorum, v.10, p.209-219, 2011. Available from: <https://www.cabi.org/isc/FullTextPDF/2011/20113290077.pdf.> Accessed: Apr. 01, 2021.

JAFARNIA S, et al. Effect of substrate and variety on some important quality and quantity characteristics of strawberry production in vertical hydroponics system. Advances in Environmental Biology, v.4, p.360-363, 2010. Available from: $<$ https://www.cabdirect.org/cabdirect/abstract/20113078218>. Accessed: Apr. 01, 2021.

LANE, J. On Neotropical Neosciara (Diptera: Sciaridae). Studia Entomologica, v.2, p.69-104, 1959.

MANSILLA, J. P., PASTORIZA, M. I. Estudio sobre la biología y control de Bradysia paupera Tuomi koski (= Bradysia difformis Frey) (Diptera: Sciaridae). Boletín Sanidad Vegetal Plagas, v.27, p.411-417, 2001. Available from: <https:/www.miteco.gob.es/ ministerio/pags/biblioteca/plagas/BSVP-27-03-411-417.pdf >. Accessed: Apr. 01, 2021.

MENZEL, F., et al. Bradysia difformis Frey and Bradysia ocellaris (Comstock): Two additional neotropical species of Bblack fungus gnats (Diptera: Sciaridae) of economic importance: A redescription and review. Annals of the Entomological Society of America, v.96, p.448-457, 2003. Available from: $<$ https://doi.org/10.1603/0013-8746(2003)096[0448:BD FABO]2.0.CO;2>. Accessed: Apr. 01, 2021. doi: 10.1603/0013-8746(2003)096[0448:BDFABO]2.0.CO;2.

MOHRIG, W. et al. Revision of the black fungus gnats (Diptera: Sciaridae) of North America. Studia dipterologica, v.19, p.141286, 2012. Available from: <https://www.cabdirect.org/cabdirect/ abstract/20133365349>. Accessed: Apr. 01, 2021.

MORAES, G. J. de, FleChTMANN, C. H. W. Manual de Acarologia. Acarologia básica e ácaros de plantas cultivadas no Brasil. 1 $1^{\mathrm{a}}$.ed. Ribeirão Preto: Holos, 2008, v.1. 288 p., 2008.

NAM, M. H. et al. Damage and potential of fungus gnat as a Fusarium vector in the strawberry plants in Korea. Acta Horticultural, v.1156, p.857-862, 2017. Available from: <https:// doi.org/10.17660/ActaHortic.2017.1156.126>. Accessed: Apr. 01, 2021. doi: 10.17660/ActaHortic.2017.1156.126.

PALENCIA, P. et al. Investigating the effect of different soilless substrates on strawberry productivity and fruit composition. Scientiae Horticulturae, v.203, p.12-19, 2016. Available from: 
$<$ https://doi.org/10.1016/j.scienta.2016.03.005>. Accessed: Apr. 01, 2021. doi: 10.1016/j.scienta.2016.03.005.

PINELI, de L de O. et al. Antioxidants and other chemical and physical characteristics of two strawberry cultivars at different ripeness stages. Journal of Food Composition and Analysis, v.24, p.11-16, 2011. Available from: <https://doi.org/10.1016/j. jfca.2010.05.004>. Accessed: Apr. 01, 2021. doi: 10.1016/j. jfca.2010.05.004.

RADIN, B. et al. Bradysia sp. em morangueiro. Ciência Rural, v.39, p.547-550, 2009. Available from: <https://doi.org/10.1590/ S0103-84782009000200036>. Accessed: Apr. 01, 2021. doi: 10.1590/S0103-84782009000200036.

RESENDE, J. T. V. de. Strawberry. Revista Brasileira de Fruticultura, v.40, 2018.
SAN-BLAS, E. et al. Biological control of the fungus gnats Bradysia difformis (Diptera, Mycetophilidae) in mushrooms with Heterorhabditis amazonensis in tropical conditions. Scientia Horticulturae, v.216, p.120-125, 2017. Available from: <https:// doi.org/10.1016/j.scienta.2017.01.003>. Accessed: Apr. 01, 2021. doi: 10.1016/j.scienta.2017.01.003.

SANTOS, A. et al. First Report and population changes of Bradysia difformis (Diptera: Sciaridae) on Eucalyptus nurseries in Brazil. Florida Entomologist, v.95 p.569-572, 2012. Available from: <https://doi.org/10.1653/024.095.0305>. Accessed: Apr. 01, 2021. doi: 10.1653/024.095.0305.

SCHÜHLI, G. S. Sciarid fungus-gnats as nuisance factor in Pinus timber yards. Brazilian Journal of Forestry Research, v.34, p.1-3, 2014. Available from: <https://doi.org/10.4336/2014.pfb.34.80.732>. Accessed: Apr. 01, 2021. doi: 10.4336/2014.pfb.34.80.732. 